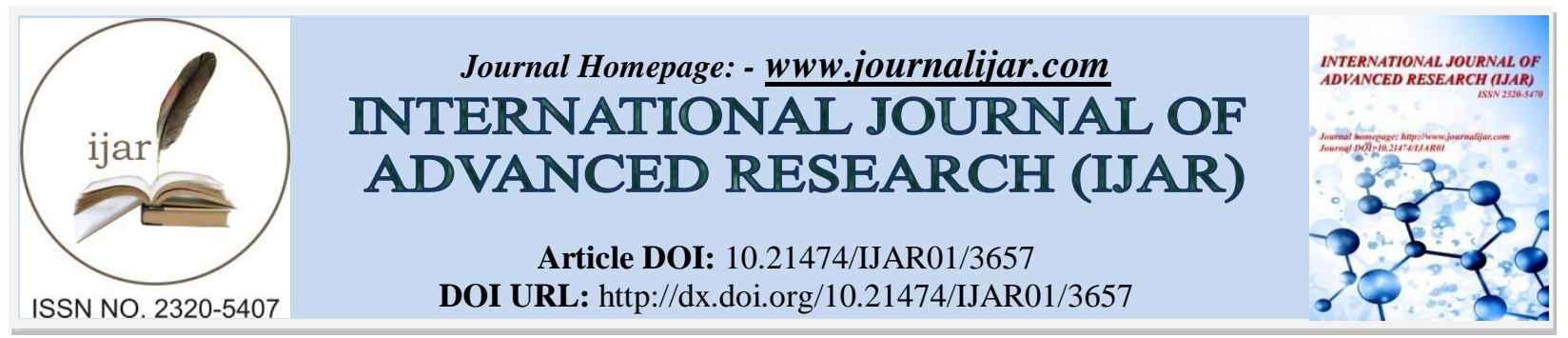

RESEARCH ARTICLE

\title{
A STUDY ON FACTORS INFLUENCING EMOTIONAL INTELLIGENCE OF TEACHERS OF MANAGEMENT EDUCATION IN COIMBATORE CITY.
}

\author{
N. Sangeetha BBM (CA)., MBA. PGDIB.,(Ph.D). \\ Research Scholar and Assistant Professor, Coimbatore Institute of Management And Technology.
}

\section{Manuscript Info}

Manuscript History

Received: 10 January 2017

Final Accepted: 05 February 2017

Published: March 2017

Key words:-

Emotional Intelligence, Influencing

factors of Emotional Intelligence,

Management education, Teachers.

\section{Abstract}

This study aimed at studying and understanding the factors influencing the Emotional Intelligence of teachers of management education in Coimbatore City and studying the relationship between the demographic variables and factors of the Emotional Intelligence. Present study is descriptive in nature and convenience sampling technique was adopted. Both primary and secondary data were collected for the study. Primary data were collected through questionnaire and the secondary data were collected from magazines, journals, online databases, websites etc. The collected were analysed using percentage analysis and ANOVA. From the analysis, certain findings were made. Based on the findings some suggestions were given and certain conclusions are drawn.

Copy Right, IJAR, 2017,. All rights reserved.

\section{Introduction:-}

The relationship between teachers and students was oriented towards just imparting knowledge in the past. This concept is gradually changing though not in a radical manner; education is not restricted with knowledge but formation of students. Developing students in courage and maturity to encounter the complexity of life is capturing the visionary educators of present day.

Current theories - The Multiple Intelligences Theory (Gardner, 1983) \& The Emotional Intelligence Theory (Mayer \& Salovey, 1995 Goleman, 1995) - point out the important of emotional intelligence for the students of higher learning. IQ alone does not guarantee the required success in the modern organizations; in fact it only counts for 20\%, and the rest goes for Emotional and Social Intelligences, and luck (Goleman, 1995).

Emotional intelligence is increasingly becoming an important concept in the workplaces, workshops and conferences are organized to help employees and managers to understand the important of Emotional Intelligence and to implement it in their work place (Abraham, 1999). If Emotional Intelligence is considered nowadays vital for success, then it becomes imperative that students of higher learning must pay more attention to the components of Emotional Intelligence.

The purpose of this study is to understand the factors influencing Emotional Intelligence of teachers of management education in various colleges. 


\section{Emotional Intelligence}

Emotional Intelligence: It is being able to monitor our own and others' feelings and emotions, to discriminate among them, and to use this to guide our thinking and actions (Salovey \& Mayer, 1990). The emotionally intelligent person is skilled in four areas: Identifying, using, understanding, and regulating emotions (Salovey \& Mayer, 1990).

According to Goleman (1995) emotional intelligence consists of five components: Knowing our emotions (selfawareness), managing them, motivating ourselves, recognizing emotions in others (empathy), and handling relationships.

Teaching emotional and social skills is very important at school, it can affect academic achievement positively not only during the year they are taught, but during the years that follow as well. Teaching these skills has a long-term effect on achievement. (Elias et al, 1991).

Richardson and Evans (1997) explored some methods for teaching social and emotional competence within a culturally diverse society. Their purpose was to help students connect with each other, in order to assist them in developing interpersonal, intrapersonal, and emotional intelligences, arguing that these intelligences are essential for personal accomplishment.

At La Salle Academy, a private school in providence, Rhode Island, students are given lessons in emotional intelligence across the curriculum. This is part of an exhaustive program in social and emotional education called "Success for Life."

Finnegan (1998) argues that schools should help students learn the abilities underlying emotional intelligence. Possessing those abilities, or even some of them, "can lead to achievement from the formal education years of the child and adolescent to the adult's competency in being effective in the workplace and in society".

People with emotional intelligence have a confidence in themselves and they know that their personal happiness is up to them and no one else. They check their emotions before labeling other people and their actions. Such people can inspire and lead and make others feel good about them, while maintaining their own integrity and sense of personal worth. People with emotional intelligence look out for their own well being, as well as that of others as they understand that life is not just about them, it's about balance.

There are two types of intelligence: rational and emotional. Deliberate, analytic reflection is the hallmark of the thinking mind, but the emotional mind is a moment quicker, springing into action on impulse unless tempered by the rational mind.

There should be a balance between emotional and rational thinking, with the emotional brain feeding into and informing the operations of the rational brain, and the rational mind refining the inputs of the emotional mind. Developing a harmony between the head and the heart can foster happiness and promote success in life.

EI is defined as the ability to process emotional information, particularly as it involves the perception, assimilation, understanding, and management of emotions (Mayer \& Cobb, 2000). Baron (1997) considers EI as an array of noncognitive capabilities, competencies, and skills that influences one's abilities in succeeding and coping with the environmental demands and pressures.

According to Hein (2005), EI is the innate potential to feel, use, communicate, recognise, remember, learn, manage and understand emotions. Goleman (1998) considers EI as the capacity for recognising our own feelings and those of others, for motivating ourselves, and for managing emotions well in ourselves and in our relationships. It describes abilities distinct from, but complementary to, academic intelligence, the purely cognitive capacities measured by IQ. Daniel Goleman's theory is one of the most widely accepted concepts of EI.

According to Goleman's emotional competence framework, EI can be viewed within a set of personal and social competencies. Table 1 illustrates the Goleman's EI competency framework. Within this framework, Goleman has indicated the factors that influence the EI levels of an individual. Goleman (2001) has also suggested that these factors could be measured and improved. Henceforth, begins the concept of learning EI and improving leadership qualities of an individual and thereby the organisation. 
Table-1:- Goleman's EI competency framework.

\begin{tabular}{|c|c|c|}
\hline & $\begin{array}{c}\text { Self } \\
\text { Personal Competence }\end{array}$ & $\begin{array}{c}\text { Other } \\
\text { Social Competence }\end{array}$ \\
\hline Recognition & $\begin{array}{l}\text { Self-Awareness } \\
\text { - } \quad \text { Emotional self-awareness } \\
\text { - } \quad \text { Accurate self-assessment } \\
\text { - Self-Confidence }\end{array}$ & \begin{tabular}{l}
\multicolumn{2}{l}{ Social Awareness } \\
- $\quad$ Empathy \\
- $\quad$ Service Orientation \\
- $\quad$ Organisational awareness
\end{tabular} \\
\hline Regulation & $\begin{array}{ll}\text { Self-Management } \\
\text { - } & \text { Self-control } \\
\text { - } & \text { Trustworthiness } \\
\text { - } & \text { Conscientiousness } \\
\text { - } & \text { Adaptability } \\
\text { - } & \text { Achievement drive } \\
& \text { Initiative }\end{array}$ & $\begin{array}{l}\text { Relationship Management } \\
\text { - } \quad \text { Developing others } \\
\text { - } \quad \text { Influence } \\
\text { - } \quad \text { Communication } \\
\text { - } \quad \text { Conflict management } \\
\text { - } \quad \text { Leadership } \\
\text { - } \quad \text { Change catalyst } \\
\text { - } \quad \text { Building blocks } \\
\text { - } \quad \text { Teamwork and collaboration }\end{array}$ \\
\hline
\end{tabular}

History of Emotional Intelligence:-

1930 - Edward Thorndike describes the concept "social intelligence" as the ability to get alone with other people.

1940 - David Wechsler suggests that affective components of intelligence may be essential to success in life.

1950 - Humanistic psychologists such as Abraham Maslow describe how people can build emotional strength.

1975 - Howard Gardner publishes the Shattered Mind, which introduces the concept of multiple intelligence.

1985 - Wayne Payne introduces the term emotional intelligence in his doctoral dissertation entitled "A study of emotion: developing emotional intelligence; self- integration; relating to fear, pain and desire".

1987 - In an article published in Mensa Magazine, Keith Beasley uses the term "emotional quotient." It has been suggested that this is the first published use of the them, although the Reuven Bar-On claims to have used the term in an unpublished version of his graduate thesis.

1990 - Psychologists Peter Salovey and John Mayer publish their landmark article, "Emotional intelligence," in the journal imagination, cognition, and personality.

1995 - The concept of emotional intelligence is popularized after publication of psychologist and New York Times science writer Daniel Goleman's book emotional intelligence: why it can matter more than IQ.

\section{Significance of the study:-}

"More students leave college because of disillusionment, discouragement, or reduced motivation than because of lack of ability or dismissal by school administration".

- The use of Emotional Intelligence to aid the student development process can address these non- academic challenges.

- Investing in the emotional development of students also impacts leadership effectiveness, both on campus and in the future.

Finally, emotional competency development benefits the career development process, promoting a successful transition from college into the workplace.

\section{Why EI is important for teachers?}

- It influences what we do

- It affects who we meet

- It determines how we look

- It decides students and teachers course of life

- It helps to express emotions appropriately instead ignore them

\section{Statement of the problem:-}

Emotional intelligence of teachers plays an important role in determining the educational institution success. Now a days, students are more sensitive and very reactive towards the action of their teachers. Emotional intelligence of teachers not only affects the students but also affect their peer group. So it is one of the important duties of every teacher to control and deliver his/her Emotional Intelligence in a positive way. 
- Teachers can't focus on their work fully when their family problem interrupts their mind. So normally they deliver negative emotions.

- Usually most of the teachers show the negative emotions when they receive negative comments from the higher authority in front of their peer group.

- Most of the times misbehaving students are subject to receive negative emotions from the teachers.

These are the major problems that every institution and the students were facing in the current scenario. This study helps to understand the factors influencing their Emotional Intelligence.

\section{Scope of the study:-}

The study of Emotional Intelligence focuses on handling of emotions by oneself and with others. There is no relation between the qualification and the intelligence level. The study is based on the evaluation of Emotional Quotient among the teachers. The reason for the study of Emotional Intelligence is that nowadays students are more sensitive and inactive. So the teachers should have a positive Emotional Intelligence that may help the students' growth as well as the institution growth because the teachers are the foundation for the students' life and for the institution. This study helps to understand the factors that influence the Emotional Intelligence of teachers of Management education.

\section{Objectives of the Study:-}

\section{Core Objective:-}

To study and understand the factors influencing the Emotional Intelligence of teachers of management education in Coimbatore City.

\section{Secondary Objectives:-}

1. To trace the theoretical perspective of Emotional Intelligence.

2. To study the relationship between the demographic variables and factors of the Emotional Intelligence.

\section{Hypotheses:-}

1. The influencing factors of Emotional Intelligence have a positive relationship when compared with Age.

2. The influencing factors of Emotional Intelligence have a positive relationship when compared with Gender.

3. The influencing factors of Emotional Intelligence have a positive relationship when compared with Working Experience.

4. The influencing factors of Emotional Intelligence have a positive relationship when compared with Marital status.

\section{Methodology:-}

Present study is descriptive in nature and convenient sampling technique was adopted. Both primary and secondary data were collected for the study. The major sources of the data used to carry out the analysis were primary data. First-hand information was collected through a questionnaire from 250 management education teachers working in various colleges in Coimbatore city. The secondary data namely literature relating to the study was gathered from the national and international journals, newspaper, magazines, articles, other records and also from web sources on the internet. Pilot study was done for 50 among the sample respondents. The data were first evaluated for their validity and Reliability. Incomplete and ambiguous responses were rejected. The tools of analysis like Percentage Analysis, ANOVA were used in the study. The Statistical Package for Social Sciences (SPSS) was used to analyse the data and draw the inference.

Table - 2:- Gender

\begin{tabular}{|l|l|l|l|}
\hline S.No & Gender & Frequency & Percent \\
\hline 1 & Male & 117 & 46.8 \\
\hline 2 & Female & 133 & 53.2 \\
\hline & Total & $\mathbf{2 5 0}$ & $\mathbf{1 0 0 . 0}$ \\
\hline
\end{tabular}

From the table it could be understood that a 53.2 percent of the teachers were female and a remaining 46.8 percent of the teachers were Male. It is understood that the Female respondents were higher in the management education appointments. 


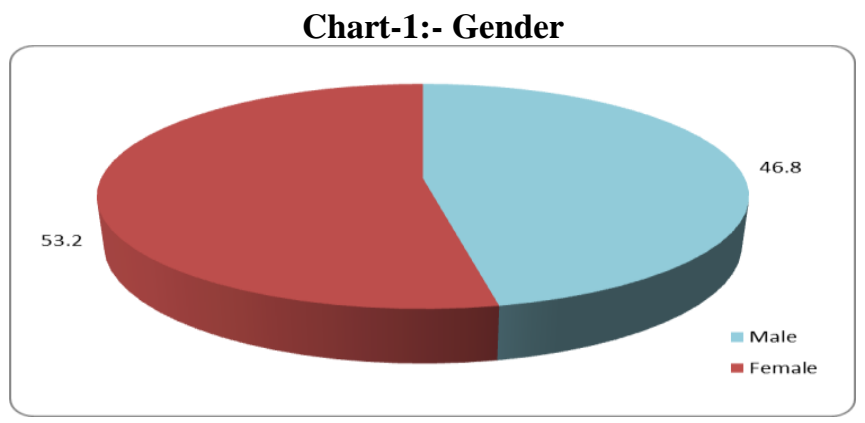

Table - 3:-Age

\begin{tabular}{|l|l|l|l|}
\hline S.No & Age & Frequency & Percent \\
\hline 1 & $20-25 \mathrm{yrs}$ & 36 & 14.4 \\
\hline 2 & $25-30 \mathrm{yrs}$ & 71 & 28.4 \\
\hline 3 & $30-35 \mathrm{yrs}$ & 57 & 22.8 \\
\hline 4 & $35-40 \mathrm{yrs}$ & 54 & 21.6 \\
\hline 5 & $>40 \mathrm{yrs}$ & 32 & 12.8 \\
\hline & Total & $\mathbf{2 5 0}$ & $\mathbf{1 0 0 . 0}$ \\
\hline
\end{tabular}

It is clear from the analysis that 28.4 percent of the teachers age ranges from 25 - 30 years, 22.8 percent of the respondents age ranges between 30 - 35 years, 21.6 percent of the respondents age ranges between $35-40$ years, 14.4 percent of the respondents age ranges between $20-25$ years, and a least of 12.8 percent of the respondents age was above 40 years.

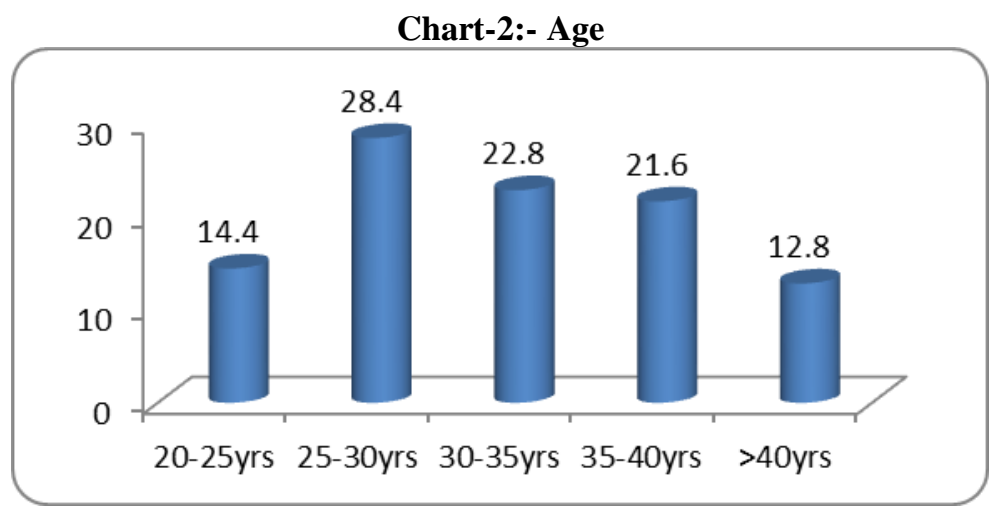

Table - 4:- Marital status

\begin{tabular}{|l|l|l|l|}
\hline S.No & Marital Status & Frequency & Percent \\
\hline 1 & Single & 39 & 15.6 \\
\hline 2 & Married & 102 & 40.8 \\
\hline 3 & Widow & 52 & 20.8 \\
\hline 4 & Divorce & 57 & 22.8 \\
\hline & Total & $\mathbf{2 5 0}$ & $\mathbf{1 0 0 . 0}$ \\
\hline
\end{tabular}

From the table it could be understood that 40.8 percent of the respondents were married, 22.8 percent of the respondents were Divorcees, 20.8 percent of them were Widow, and a least of 15.6 percent of them were Single. It is well understood from the table that a 40.8 percent of the respondents were married. 


\section{Chart-3:- Marital Status}

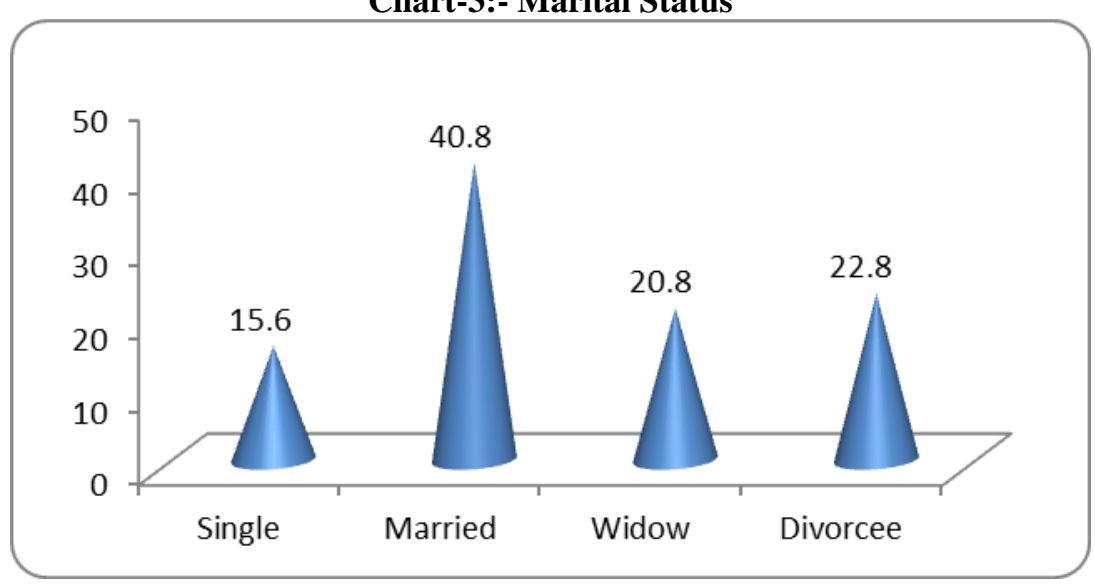

Table - 5:- Work Experience

\begin{tabular}{|l|l|l|l|}
\hline S.No & Work Experience & Frequency & Percent \\
\hline 1 & Less than 5 yrs & 33 & 13.2 \\
\hline 2 & $5-10 \mathrm{yrs}$ & 72 & 28.8 \\
\hline 3 & $10-15 \mathrm{yrs}$ & 53 & 21.2 \\
\hline 4 & $15-20 \mathrm{yrs}$ & 52 & 20.8 \\
\hline 5 & Above 20yrs & 40 & 16.0 \\
\hline & Total & $\mathbf{2 5 0}$ & $\mathbf{1 0 0 . 0}$ \\
\hline
\end{tabular}

It could be learnt from the table that 28.8 percent of the respondents have an experience of 5- 10 years, 21.2 percent of the respondents have an experience of $10-15$ years, 20.8 percent of them have an experience of $15-20$ years, 16 percent of the respondents have an experience of above 20 years, 13.2 percent of the respondents have an experience of less than 5 years.

Chart-4:- Work Experience

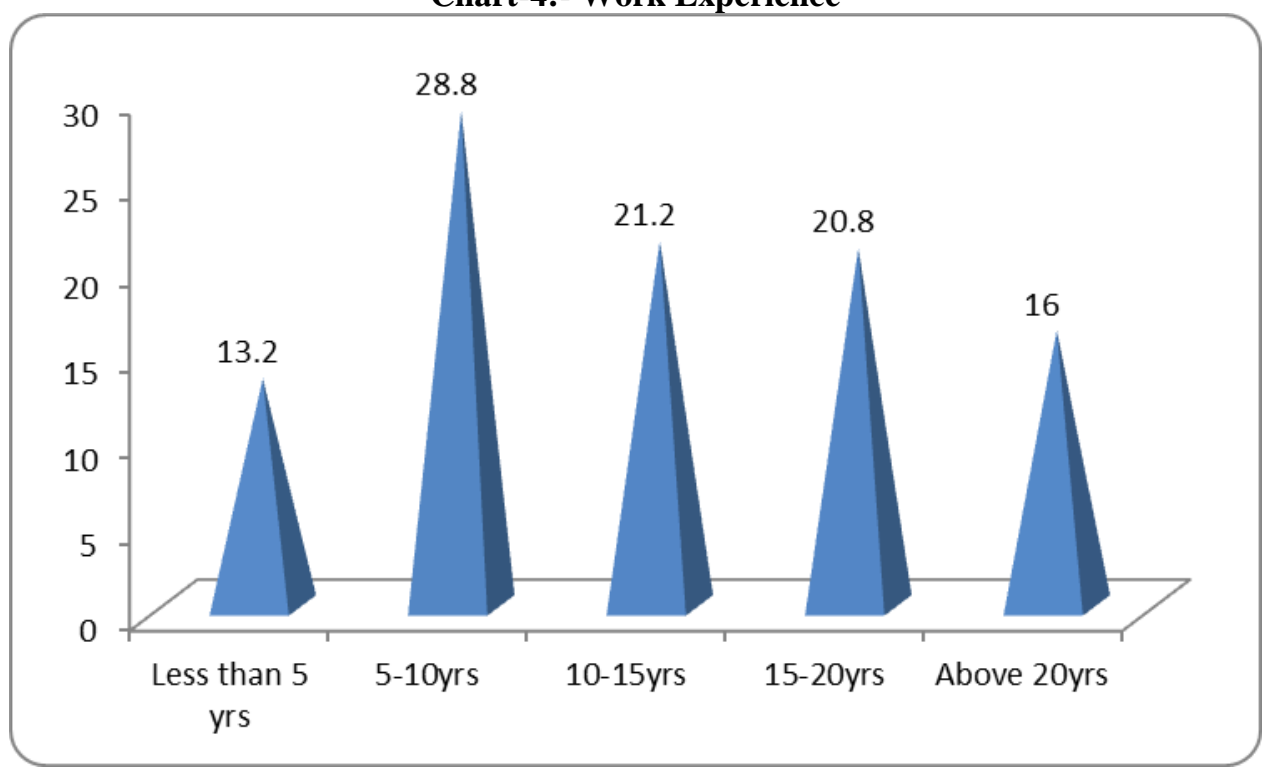


Table - 6:- Influencing Factors of Emotional Intelligence

\begin{tabular}{|c|c|c|c|c|}
\hline S.No & Statements & Agree & Disagree & Total \\
\hline 1 & I enjoy establishing a good working relationship with a group & $\begin{array}{l}110 \\
(44)\end{array}$ & $\begin{array}{l}140 \\
(56)\end{array}$ & 250 \\
\hline 2 & They often seem just not motivated to join in & $\begin{array}{l}134 \\
(53.6)\end{array}$ & $\begin{array}{l}116 \\
(46.4)\end{array}$ & 250 \\
\hline 3 & $\begin{array}{l}\text { I am always worried I am going to be asked the question that will catch me } \\
\text { out. }\end{array}$ & $\begin{array}{l}135 \\
(53.6)\end{array}$ & $\begin{array}{l}116 \\
(46.4)\end{array}$ & 250 \\
\hline 4 & When teaching I see myself as making the best of a bad situation & $\begin{array}{l}73 \\
(29.2)\end{array}$ & $\begin{array}{l}177 \\
(70.8)\end{array}$ & 250 \\
\hline 5 & Although I get anxious, I feel confident and relaxed in my role. & $\begin{array}{l}124 \\
(49.6)\end{array}$ & $\begin{array}{l}126 \\
(50.4)\end{array}$ & 250 \\
\hline 6 & There always seem to be learners who are simply lazy. & $\begin{array}{l}128 \\
(51.2)\end{array}$ & $\begin{array}{l}122 \\
(48.8)\end{array}$ & 250 \\
\hline 7 & Sometimes I wonder what is the point & $\begin{array}{l}142 \\
(51.2)\end{array}$ & $\begin{array}{l}108 \\
(43.2)\end{array}$ & 250 \\
\hline 8 & I do worry I am going to be found out as knowing as much as they think. & $\begin{array}{l}111 \\
(44.4) \\
\end{array}$ & $\begin{array}{l}139 \\
(55.6) \\
\end{array}$ & 250 \\
\hline 9 & It is really like casting pearls before swine. & $\begin{array}{l}139 \\
(55.6)\end{array}$ & $\begin{array}{l}111 \\
(44.4)\end{array}$ & 250 \\
\hline 10 & I sense that nothing really changes. & $\begin{array}{l}123 \\
(49.2) \\
\end{array}$ & $\begin{array}{l}127 \\
(50.8) \\
\end{array}$ & 250 \\
\hline 11 & I often feel that I have let at least some of the learners down. & $\begin{array}{l}125 \\
(50.0)\end{array}$ & $\begin{array}{l}125 \\
(50.0)\end{array}$ & 250 \\
\hline 12 & $\begin{array}{l}\text { When I approach a new session I expect that both they and } i \text { will enjoy } \\
\text { ourselves and learn something useful. }\end{array}$ & $\begin{array}{l}111 \\
(44.4)\end{array}$ & $\begin{array}{l}139 \\
(55.6)\end{array}$ & 250 \\
\hline 13 & $\begin{array}{l}\text { No matter how much effort I put in there will always be some who are just } \\
\text { not going to get it. }\end{array}$ & $\begin{array}{l}128 \\
(51.2)\end{array}$ & $\begin{array}{l}122 \\
(48.8)\end{array}$ & 250 \\
\hline 14 & I am always conscious of some members not getting much from it. & $\begin{array}{l}128 \\
(51.2)\end{array}$ & $\begin{array}{l}122 \\
(48.8)\end{array}$ & 250 \\
\hline 15 & I enjoy corresponding to the challenges each new session brings & $\begin{array}{l}122 \\
(48.8) \\
\end{array}$ & $\begin{array}{l}128 \\
(51.2)\end{array}$ & 250 \\
\hline 16 & Sometimes I think they look as despondent as I feel. & $\begin{array}{l}124 \\
(49.6)\end{array}$ & $\begin{array}{l}126 \\
(50.4)\end{array}$ & 250 \\
\hline
\end{tabular}

The above table shows how many percent of respondents agree and disagree to the statements regarding the factors influencing the Emotional Intelligence. The numbers within the brackets indicate the respective percentage value. These statements are clustered into four life positions and those are given below.

Table-6.1 Get Rid of Position

\begin{tabular}{|l|l|l|l|l|}
\hline S.NO & GET RID OF POSITION & Agree & Disagree & Total \\
\hline 2 & They often seem just not motivated to join in & $\begin{array}{l}\mathbf{1 3 4} \\
\mathbf{( 5 3 . 6 )}\end{array}$ & $\begin{array}{l}116 \\
(46.4)\end{array}$ & 250 \\
\hline 6 & There always seem to be learners who are simply lazy. & $\begin{array}{l}\mathbf{1 2 8} \\
\mathbf{( 5 1 . 2 )}\end{array}$ & $\begin{array}{l}122 \\
(48.8)\end{array}$ & 250 \\
\hline 9 & It is really like casting pearls before swine. & $\begin{array}{l}\mathbf{1 3 9} \\
\mathbf{( 5 5 . 6 )}\end{array}$ & $\begin{array}{l}111 \\
(44.4)\end{array}$ & 250 \\
\hline 13 & $\begin{array}{l}\text { No matter how much effort I put in there will always be some who } \\
\text { are just not going to get it. }\end{array}$ & $\begin{array}{l}\mathbf{1 2 8} \\
\mathbf{( 5 1 . 2 )}\end{array}$ & $\begin{array}{l}122 \\
(48.8)\end{array}$ & 250 \\
\hline
\end{tabular}

The agreeability towards the statements 2,6,9,13 indicates that the teaching professionals spends time and on the idea on "Defensive or Get Rid of Position". These statements responds to the life position that "I am ok, You are not ok. A defensive position where generally see the teaching professionals as blameless but good at seeing failings in others. 
Table-6.2 Get Away Position

\begin{tabular}{|l|l|l|l|l|}
\hline S.NO & GET AWAY POSITION & Agree & Disagree & Total \\
\hline 3 & $\begin{array}{l}\text { I am always worried I am going to be asked the question that will catch me } \\
\text { out. }\end{array}$ & $\begin{array}{l}\mathbf{1 3 5} \\
\mathbf{( 5 3 . 6})\end{array}$ & $\begin{array}{l}116 \\
(46.4)\end{array}$ & 250 \\
\hline 8 & I do worry I am going to be found out as knowing as much as they think. & $\begin{array}{l}\mathbf{1 3 9} \\
\mathbf{( 5 5 . 6 )}\end{array}$ & $\begin{array}{l}111 \\
(44.4)\end{array}$ & 250 \\
\hline 11 & I often feel that I have let at least some of the learners down & $\begin{array}{l}\mathbf{1 2 5} \\
\mathbf{( 5 0 . 0 )}\end{array}$ & $\begin{array}{l}125 \\
(50.0)\end{array}$ & 250 \\
\hline 14 & I am always conscious of some members not getting much from it. & $\begin{array}{l}\mathbf{1 2 8} \\
\mathbf{( 5 1 . 2 )}\end{array}$ & $\begin{array}{l}122 \\
(48.8)\end{array}$ & 250 \\
\hline
\end{tabular}

The agreeability towards the statements 3,8,11 and 14 indicates that the teaching professionals spends time on the idea on "Get Away Position". These statements indicate to the life position that "I am not ok, you are ok". Where in the teaching professionals find fault with themselves and feels that others are capable and as "Potential prosecutors".

Table-6.3 Get -Nowhere- With Position

\begin{tabular}{|l|l|l|l|l|}
\hline S.NO & GET- NOWHERE-WITH POSITION & Agree & Disagree & Total \\
\hline 4 & When teaching I see myself as making the best of a bad situation & $\begin{array}{l}73 \\
(29.2)\end{array}$ & $\begin{array}{l}\mathbf{1 7 7} \\
\mathbf{( 7 0 . 8 )}\end{array}$ & 250 \\
\hline 7 & Sometimes I wonder what is the point & $\begin{array}{l}\mathbf{1 4 2} \\
(\mathbf{5 1 . 2})\end{array}$ & $\begin{array}{l}108 \\
(43.2)\end{array}$ & 250 \\
\hline 10 & I sense that nothing really changes. & $\begin{array}{l}123 \\
(49.2)\end{array}$ & $\begin{array}{l}\mathbf{1 2 7} \\
\mathbf{( 5 0 . 8 )}\end{array}$ & 250 \\
\hline 16 & Sometimes I think they look as despondent as I feel. & $\begin{array}{l}124 \\
(49.6)\end{array}$ & $\begin{array}{l}\mathbf{1 2 6} \\
(\mathbf{5 0 . 4})\end{array}$ & 250 \\
\hline
\end{tabular}

The agreeability towards the statements 4,7,10 and 16 indicates that the teaching professionals spends time on the idea on "Get nowhere with" position. These statements indicate to the life position that "I am not ok, you are not ok". And can be acknowledged as the teaching professionals are having negative view of yourself and everyone else and feel "Despair".

Table-6.4

\begin{tabular}{|c|c|c|c|c|}
\hline S.NO & GET ON WITH POSITION & Agree & Disagree & Total \\
\hline 1 & I enjoy establishing a good working relationship with a group & $\begin{array}{l}110 \\
(44)\end{array}$ & $\begin{array}{l}140 \\
(56)\end{array}$ & 250 \\
\hline 5 & Although I get anxious, I feel confident and relaxed in my role. & $\begin{array}{l}124 \\
(49.6)\end{array}$ & $\begin{array}{l}126 \\
(50.4)\end{array}$ & 250 \\
\hline 12 & $\begin{array}{l}\text { When I approach a new session I expect that both they and I will enjoy } \\
\text { ourselves and learn something useful. }\end{array}$ & $\begin{array}{l}111 \\
(44.4)\end{array}$ & $\begin{array}{l}139 \\
(55.6)\end{array}$ & 250 \\
\hline 15 & I enjoy corresponding to the challenges each new session brings & $\begin{array}{l}122 \\
(48.8)\end{array}$ & $\begin{array}{l}128 \\
(51.2)\end{array}$ & 250 \\
\hline
\end{tabular}

The agreeability towards the statements on 1,5,12 and 15 indicates that the teaching professionals spends time and on the idea on "Get on with" position. These statements indicate to the life position that "I am ok, you are ok". These statements link to the life position I am ok and you are ok. The teaching professionals are open minded and tackle problems.

Analysis of Variance:-

H1 : The influencing factors of emotional intelligence have a positive relationship when compared with Age. 
Table - 7:- The influencing factors of emotional intelligence have a positive relationship when compared with Age.

\begin{tabular}{|c|c|c|c|c|c|c|c|}
\hline \multicolumn{2}{|l|}{ Source of variance } & Sum of Squares & Df & Mean Square & $\mathbf{F}$ & Sig. & Result \\
\hline \multirow{3}{*}{ Defensive position } & Between Groups & 78.389 & 4 & 19.597 & 3.067 & $.017 *$ & $\mathrm{~S}$ \\
\hline & Within Groups & 1565.547 & 245 & 6.390 & & & \\
\hline & Total & 1643.936 & 249 & & & & \\
\hline \multirow{3}{*}{ Get rid of position } & Between Groups & 66.758 & 4 & 16.690 & 2.915 & $.022 *$ & $\mathrm{~S}$ \\
\hline & Within Groups & 1402.558 & 245 & 5.725 & & & \\
\hline & Total & 1469.316 & 249 & & & & \\
\hline \multirow{3}{*}{ Get away position } & Between Groups & 557.483 & 4 & 139.371 & 29.001 & $.000 * *$ & $\mathrm{~S}$ \\
\hline & Within Groups & 1177.401 & 245 & 4.806 & & & \\
\hline & Total & 1734.884 & 249 & & & & \\
\hline \multirow{3}{*}{ Get on with position } & Between Groups & 193.555 & 4 & 48.389 & 7.485 & $.000^{* * * *}$ & $\mathrm{~S}$ \\
\hline & Within Groups & 1583.809 & 245 & 6.465 & & & \\
\hline & Total & 1777.364 & 249 & & & & \\
\hline
\end{tabular}

*significant at $5 \%, * *$ Significant at $1 \%$

$\mathrm{H} 2$ : The influencing factors of emotional intelligence have a positive relationship when compared with Gender.

Table - 8:- The influencing factors of emotional intelligence have a positive relationship when compared with Gender

\begin{tabular}{|c|c|c|c|c|c|c|c|}
\hline \multicolumn{2}{|c|}{ Source of variance } & Sum of Squares & Df & Mean Square & $\mathbf{F}$ & Sig. & Result \\
\hline \multirow{3}{*}{$\begin{array}{l}\text { Defensive } \\
\text { position }\end{array}$} & Between Groups & .109 & 1 & .109 & .016 & .898 & NS \\
\hline & Within Groups & 1643.827 & 248 & 6.628 & & & \\
\hline & Total & 1643.936 & 249 & & & & \\
\hline \multirow{3}{*}{$\begin{array}{l}\text { Get rid of } \\
\text { position }\end{array}$} & Between Groups & .295 & 1 & .295 & .050 & .824 & NS \\
\hline & \begin{tabular}{|l|} 
Within Groups \\
\end{tabular} & 1469.021 & 248 & 5.923 & & & \\
\hline & Total & 1469.316 & 249 & & & & \\
\hline \multirow{3}{*}{$\begin{array}{l}\text { Get away } \\
\text { position }\end{array}$} & Between Groups & 32.989 & 1 & 32.989 & 4.807 & $.029 *$ & $\mathrm{~S}$ \\
\hline & Within Groups & 1701.895 & 248 & 6.862 & & & \\
\hline & Total & 1734.884 & 249 & & & & \\
\hline \multirow{3}{*}{$\begin{array}{l}\text { Get on with } \\
\text { position }\end{array}$} & Between Groups & 36.961 & 1 & 36.961 & 5.267 & $.023^{*}$ & $\mathrm{~S}$ \\
\hline & Within Groups & 1740.403 & 248 & 7.018 & & & \\
\hline & Total & \begin{tabular}{|l|}
1777.364 \\
\end{tabular} & 249 & & & & \\
\hline
\end{tabular}

*significant at $5 \%, * *$ Significant at $1 \%$

$\mathrm{H} 3$ : The influencing factors of emotional intelligence have a positive relationship when compared with Working experience.

Table - 9:- The influencing factors of emotional intelligence have a positive relationship when compared with Working experience

\begin{tabular}{|l|l|l|l|l|l|l|l|}
\hline Source of variance & Sum of Squares & Df & Mean Square & F & Sig. & Result \\
\hline \multirow{2}{*}{$\begin{array}{l}\text { Defensive } \\
\text { position }\end{array}$} & Between Groups & 126.067 & 4 & 31.517 & 5.087 & $.001^{* *}$ & S \\
\cline { 2 - 8 } & Within Groups & 1517.869 & 245 & 6.195 & & & \\
\cline { 2 - 8 } $\begin{array}{l}\text { Get rid } \\
\text { position }\end{array}$ & Total & 1643.936 & 249 & & & & \\
\hline \multirow{2}{*}{$\begin{array}{l}\text { Get away } \\
\text { position }\end{array}$} & Between Groups & 23.218 & 4 & 5.805 & .983 & .417 & NS \\
\cline { 2 - 8 } & Within Groups & 1446.098 & 245 & 5.902 & & & \\
\hline \multirow{2}{*}{$\begin{array}{l}\text { Get on } \\
\text { position }\end{array}$} & Between Groups & 1469.316 & 249 & & & & \\
\cline { 2 - 8 } & Within Groups & 1359.379 & 4 & 94.845 & 17.143 & $.000^{* *}$ & $\mathrm{~S}$ \\
\cline { 2 - 8 } & Total & 1734.884 & 245 & 5.533 & & & \\
\cline { 2 - 8 } & Wetween Groups & 569.189 & 249 & & & & \\
\cline { 2 - 8 } & Total Groups & 1208.175 & 245 & 4.931 & & & \\
\hline
\end{tabular}

*significant at $5 \%, * *$ Significant at $1 \%$

$\mathrm{H} 4$ : The influencing factors of emotional intelligence have a positive relationship when compared with Marital status. 
Table - 10:- The influencing factors of emotional intelligence have a positive relationship when compared with Marital status.

\begin{tabular}{|c|c|c|c|c|c|c|c|}
\hline \multicolumn{2}{|c|}{ Source of variance } & $\begin{array}{l}\text { Sum of } \\
\text { Squares }\end{array}$ & Df & Mean Square & $\mathbf{F}$ & Sig. & Result \\
\hline \multirow{3}{*}{$\begin{array}{l}\text { Defensive } \\
\text { position }\end{array}$} & Between Groups & 15.122 & 3 & 5.041 & .761 & .517 & NS \\
\hline & Within Groups & 1628.814 & 246 & 6.621 & & & \\
\hline & Total & 1643.936 & 249 & & & & \\
\hline \multirow{3}{*}{$\begin{array}{l}\text { Get rid of } \\
\text { position }\end{array}$} & Between Groups & 27.181 & 3 & 9.060 & 1.546 & .203 & NS \\
\hline & Within Groups & 1442.135 & 246 & 5.862 & & & \\
\hline & Total & 1469.316 & 249 & & & & \\
\hline \multirow{3}{*}{$\begin{array}{l}\text { Get away } \\
\text { position }\end{array}$} & Between Groups & 36.349 & 3 & 12.116 & 1.755 & .156 & NS \\
\hline & Within Groups & 1698.535 & 246 & 6.905 & & & \\
\hline & Total & 1734.884 & 249 & & & & \\
\hline \multirow{3}{*}{$\begin{array}{l}\text { Get on with } \\
\text { position }\end{array}$} & Between Groups & 54.110 & 3 & 18.037 & 2.575 & $.055^{*}$ & $\mathrm{~S}$ \\
\hline & Within Groups & 1723.254 & 246 & 7.005 & & & \\
\hline & Total & 1777.364 & 249 & & & & \\
\hline
\end{tabular}

*significant at $5 \%, * *$ Significant at $1 \%$

\section{Findings:-}

- 53.2 percent of the teachers were female and a remaining 46.8 percent of the teachers were Male. It is understood that the Female respondents were higher in the B- school appointments.

- 28.4 percent of the teachers age ranges from 25 - 30 years, 22.8 percent of the respondents age ranges between $30-35$ years, 21.6 percent of the respondents age ranges between $35-40$ years, 14.4 percent of the respondents age ranges between $20-25$ years, and a least of 12.8 percent of the respondents age was above 40 years.

- 40.8 percent of the respondents were married, 22.8 percent of the respondents were Divorcees, 20.8 percent of them were Widow, and a least of 15.6 percent of them were Single. It is well understood from the table that a 40.8 percent of the respondents were married.

- 28.8 percent of the respondents have an experience of 5- 10 years, 21.2 percent of the respondents have an experience of 10-15 years, 20.8 percent of them have an experience of $15-20$ years, 16 percent of the respondents have an experience of above 20 years, 13.2 percent of the respondents have an experience of less than 5 years.

- The agreeability towards the statements on They often seem just not motivated to join in, There always seem to be learners who are simply lazy, It is really like casting pearls before swine, No matter how much effort I put in there will always be some who are just not going to get it, indicates that the teaching professionals spends time and on the idea on "Get rid of Position". These statements respond to the life position that "I am ok, you are not ok. A defensive position where generally see the teaching professionals as blameless but well at seeing failings in others.

- The agreeability towards the statements on, I am always worried I am going to be asked the question that will catch me out, I do worry I am going to be found out as knowing as much as they think, I often feel that I have let at least some of the learners down, I am always conscious of some members not getting much from it. Indicates that the teaching professionals spends time and on the idea on "Get away from Position". These statements indicate to the life position that "I am not ok, you are ok". Where in the teaching professionals find fault with themselves and feels that others are capable and as "Potential prosecutors".

- The agreeability towards the statements on when teaching I see myself as making the best of a bad situation, Sometimes I wonder what is the point, I sense that nothing really changes, Sometimes I think they look as despondent as i feel, indicates that the teaching professionals spends time and on the idea on "Get nowhere with position. These statements indicate to the life position that I am ok, you are ok". And can be acknowledged as the teaching professionals are having negative view of yourself and everyone else and feel "Despair".

- The agreeability towards the statements on I enjoy establishing a good working relationship with a group, Although I get anxious, I feel confident and relaxed in my role, When I approach a new session i expect that both they and i will enjoy ourselves and learn something useful, I enjoy corresponding to the challenges each new session brings, indicates that the teaching professionals spends time and on the idea on "Get on with" 
position. These statements indicate to the life position that "I am ok, you are ok". These statements link to the life position I am ok and you are ok. The teaching professionals are opening minded and tackle problems.

\section{Results of hypothesis:-}

1. The influencing factors of emotional intelligence have a positive relationship when compared with Age.

2. The influencing factors of emotional intelligence have a positive relationship when compared with Gender.

3. The influencing factors of emotional intelligence have a positive relationship when compared with Working Experience.

4. The influencing factors of emotional intelligence have a positive relationship when compared with Marital status.

\section{Suggestions:-}

1. Emotional literacy can be introduced into the standard curriculum of Faculty Development Programmes.

2. Teachers can be given Affirmation training which helps build in their self- confidence and self -esteem not only in their teaching profession but in their personality too.

3. Students can be given orientations on Emotional Intelligence before even they step in to their curriculum which may help in better co-operation with the teachers.

4. Provision of good organization climate from the institutions will induce positive emotions in teachers.

5. Relaxation and recreation programmes can be organized for the teachers.

\section{Conclusion:-}

It is found that the teachers are aware of overt behavior which helps them to indentify the emotions. When they are capable of identifying the emotions then they can understand and manage their emotions. This means that they are emotionally intelligent. The study reveals that the respondents have a high evel of emotional awareness. This is good sign. In their reaction they seem to be wiser and everyone wants to have healthy relationship with in defense of their position, power and other factor. And in handling grievances and problems they adopt a smooth way of expressing their feelings, redressing grievances and solving problem. The study emphasizes the importance and the value of imparting emotional intelligence through continuous Faculty Development Programs by claiming that teachers with emotional intelligence skills will be able to maintain better classroom management. Thus the study will helps the teachers to identify the situations in which the negative emotions arises and help them to overcome those through various coping strategies like relaxation and recreation programmes. This will directly or indirectly create positive emotions in them.

\section{References:-}

1. Armin Mahmoudi ,International Conference on Humanities, Society and Culture, IPEDR Vol.20 (2011), IACSIT Press, Singapore.

2. Bar-On R (2006). The Bar-On model of emotional Social intelligence (ESI) Psicothema 18, Suppl., 13-25.

3. Gardner,H, Multiple intelligences: The Theory in Practice. New York, NY: Basic Books. 272

4. Goleman, D. , Emotional Intelligence. New York: Bantam.

5. Goleman, D. , Working with emotional intelligence. New York, NY: Bantam Books.

6. Alan Mortiboys, Teaching with Emotional Intelligence - A step by step guide for higher and further education Professionals, London and New york, Routledge, Second Edition, (P:24-25)

\section{Website}

1. www.eiconsortium.org 